\title{
An Influential Technological Assistance: Consulting English Monolingual Dictionary Application in Evaluating Student's English Writing
}

\author{
Muarfian Suryanudin \\ Kresna Language Institute \\ muarfiansuryanudin@gmail.com
}

\begin{abstract}
This research was aimed to describe English Monolingual Dictionary Application, time to consult it, reasons to consult, and the advantages of consulting it in evaluating student's English writing.The method of this study used descriptive qualitative and two kinds of instruments: interview and documentation. There were three teachers being interviewed. This research resulted that they consulted Oxford Advance Learner's Dictionary (OALD) $9^{\text {th }}$ edition and Longman Dictionary of Contemporary English (LDOCE) $6^{\text {th }}$ edition available on their own mobile phones. The teachers agreed that they must have consulted their English Monolingual Dictionary Application every time they found unfamiliar words during teaching academic writing especially during evaluating student's writing. They consulted their English Monolingual Dictionary Application in view of some factors; to confirm meaning, to check spelling, to check the examples of sentences, to check word classes, meaning, and to know whether the words used were grammatically applied well or not and to find synonym for paraphrase. The results of the research suggested that teachers consulted English Monolingual Dictionary Application because this dictionary provided so much help to support teaching in the class especially when evaluating student's writing product.
\end{abstract}

Keywords: Consulting Dictionary, English Monolingual Dictionary Application, Evaluating Writing, And Mobile Monolingual Learner Dictionary.

\section{Introduction}

In indirect communication (writing), grammar plays a great role in a proper understanding of languages. Nevertheless, there is something more fundamental than grammar to master. That is vocabulary. Vocabulary should 
be mastered by English learners; moreover, English teachers because they assess students' writing product. In line with the statements above, teachers should also learn the vocabularies and they should have more vocabularies than their students. It is certainty that English teachers need source to gain vocabulary accurately. The solution for it is dictionary. Technology has developed rapidly; accordingly, the use of monolingual Learner's Dictionary is more straightforward as dictionary right now has been available on mobile. Due to this existence, teachers are hopefully able to optimize students' vocabulary usage, spelling, and soon on in students' writing product. Thornton and Houser cited in Kenning, 2007:193) expresses that acquiring vocabulary through application on mobile device is much more effective than through other medias like papers, or Internet. The phenomenon of teachers consulting English Monolingual Dictionary Application is mostly found in non-formal education, especially English courses because of the condition that is semi-formal, in addition the level of vocabularies is more various from basic level to advanced level. It is found at English course called KRESNA English Institute. The teachers there use Monolingual Learner's Dictionary on their smartphone to support their teaching such as checking spelling, pronunciation, word definition, and so on. At class and they also use it for reference. 


\section{Literature Review}

In teaching, teachers play some roles. Harmer (2004: 330) says that when the teacher asks students to write, they play three roles, i.e. a motivator, a resource, and a feedback provider. He also stated that writing has four stages. They are planning, drafting, editing and revising, and final revision. It can be concluded that to teach writing well at least teachers should implement those stages.

According to Brown (2001: 357), the categories for evaluating writing are: content, organization, discourse, syntax, vocabulary, and mechanics. Therefore, the course undoubtedly contributes to the development and support of more interactive strategies. Students also have an easy consult to ample materials, which they can exploit on their own from the cosines of their homes. They can get immediate feedback on exercises. If they have a problem, they can contact a tutor and they do not have to wait until next lesson. In the course, students usually have three assignments. They are as follows: making a descriptive, cause and effect texts, finally, they upgrade one of those writing into essay.

One of the categories to evaluate students's writing is vocabulary. Teachers require references to back up their needs. That is the reason why teachers must consult monolingual dictionary. Nowadays, Monolingual dictionaries have been available on application form on Mobile phone. Klopfer and Squire (2008) describe the affordances of mobile phones as: portability, social interactivity, context, sensitivity, connectivity. 
In teaching writing, there are some problems for students to write. Ibnian (2017:197) claims that writing is difficult owing to some factors. The study indicates that lack of ideas is the most difficult problem faced by Jordania EFL students in writing class, followed by incorrect use of mechanics of writing. The study also reveals that lack of clear assessment instrument and marking schemes occupies the third rank, while time restriction ranks fourth. The unsuitable methods of teaching writing and vocabulary restriction occupy the fifth and the sixth ranks respectively, while inappropriateness and lack of materials for consulting occupy the seventh and the eight ranks. Finally, grammar difficulties and lack teacher's help ranked the ninth and the tenth respectively.

In addition, Msanjila (2005:15) stated that there were six common problems occurring during writing: capitalization problem, punctuation problem, inexplicitness or fuzziness, poor organization or illogical sequence, spelling problem, and the last is grammatical errors. It appears that out of the six writing problems, three are very crucial, including: the misuse of capital letters, inadequate use of punctuation marks and inexplicitness or fuzziness. Their impact is more serious than the other problems because the intended meaning is often misconceived. Both teachers and students should pay attention to them to achieve good writing assignment. Due to the advantages of English Monolingual Dictionary Application; moreover, it has been available on mobile phone it is expected 
teachers to consult English Monolingual Dictionary Application; therefore, teachers can maximize the evaluation towards student's writing product.

\section{Method}

This research used descriptive qualitative method. It was conducted at KRESNA English Language Institute. It was located at Asparaga Street 15A, Pare - Kediri. The researcher focused on academic writing program held on 10 July 2019 - 25 July 2019 . There were three teachers interviewed. They were Mr. Asyrof, Mr. Adzim, and Mr. Farid. They have been teaching English at KRESNA for more than 7 years. In addition, they have been using English Monolingual Dictionary Application since years. The technique of collecting data used was interview, and documentation the instrument used was interview guidelines, screenshots of some feature on application. The researcher analyzes the data by using descriptive analysis and the data are described by the researcher's own sentences. To create trustworthiness of the data, the researcher used technique of data triangulation, method of triangulation, and review informant to examine the credibility of data.

\section{Results and Discussions}

Based on the research conducted, the first informant, Mr. Asyrof, consulted a monolingual learner's dictionary on his phone, namely Oxford 
Advance Learner's Dictionary (OALD) $9^{\text {th }}$. he chose those applications was due to several features supporting the activities in academic writing program. The second informant, Mr. Farid, told that he consulted one English Monolingual Dictionary Application. It was Longman Dictionary of Contemporary English (LDOCE) $6^{\text {th }}$. He considered that it had complete features that he needed to support his teaching and evaluating activity in academic writing program. The last informant, Mr. Adzim, consulted two mobile monolingual learner's dictionaries. He said, "I usually use Oxford and Longman." He chose it, since they had various features and were easy to use; moreover, they have grammar, sentence examples, word definition, and the correct pronunciation of the words even he didn't really run the application for it made those applications became more attractive.

Mr. Asyrof always consulted his mobile phone to check the new or unfamiliar vocabulary for him both in the classroom during teaching and when he evaluated his students' writing products. To check it on English Monolingual Dictionary Application was a must for him because it was the only source that could confirm spelling and definition problems that he faced; moreover, it could help him to optimize the word usage of his students' writing product. Mr. Farid stated that in academic writing, he tended to correct the grammar, because he considered that through correct grammar, the information delivered in the text could be obtained completely by the readers. He always kept his English Monolingual Dictionary Application with him, so that when he required to check the parts of speech 
of unfamiliar words he found while teaching and evaluating students' writing product. The words occurring in academic writing were sometimes unpredictable. It depended on the students' proficiency in academic writing class.

Mr. Asyrof explained that in academic writing, the emphasis of the writing was diction; thus, when the students wanted to find the most appropriate diction, they had to find the complete information about the words, for example, the parts of speech of the words because it will determine the meaning and the usage of the word, e.g. "Feed" as a verb means to give food to a person or an animal, while "feed" as a noun means food for animals. Here, the role of the teachers was to guide his students to get the diction through English monolingual dictionary application. Furthermore, he stated that the features on the English Monolingual Dictionary Application such as collocation and thesaurus could help him a lot to get the synonyms of words and the combinations of words that mostly existed in academic writing. In addition, he mentioned that the most frequently reasons for consulting English Monolingual Dictionary Application as follows: to check spelling, to confirm the meaning or the definition of words, examples of word usage into a sentence, to find collocations and thesaurus, and to look for related word and look up frequency information.

Mr. Farid expressed his reasons why he consulted his English Monolingual Dictionary Application. Firstly, he said that he had 
responsibility to evaluate his student's writing products, the problems must exist when doing it; moreover, the texts that he evaluated had been prepared well by students, so he required English Monolingual Dictionary Application to confirm every single word that he thought it was not appropriate with the contexts of the information. From his statements, he told that the most frequent reason for consulting his English Monolingual Dictionary Application was to check its grammatical correctness.

From those informants, the first informant, Mr. Asyrof, became the main focus because he was the only teacher who was active to teach on that period while the others were not. Finally, to support this research, the writer a student's paper considered having more various words that made him consulted his English Monolingual Dictionary Application. The first reason of consulting the English Monolingual Dictionary Application was to confirm some meanings such as "embroiled and condemn" that are excerpted from (...has been embroiled in...) and (...will condemn Indonesia...). Embroiled is to involve somebody/yourself in an argument or a difficult situation, while condemn is to express very disapproval of somebody / something, usually for moral reasons. Then the informant one considered they were suitable for the context. Second reason was to check the spelling. On the student's paper there is a word considered unfamiliar. It is "confiction" that was excerpted from (...was the confiction...) after getting that word, informant 1 checks it on his English Monolingual Dictionary Application; however, he could not find it; then, he typed the 4 
initial words to find another possible word to replace it, finally he found "confiscation" whose meaning was "the act of taking something away from somebody, especially as a punishment". The third reason was to check the use in a sentence of "since" as the alternative of because through the example of sentences. Eventually, the use of is a conjunction whose meaning is because should be preceded by a comma (,). The following reason was to consult the words "clean government", he wants to convince that the word "clean" is appropriate to that context. Another meaning of clean is "not illegal".

During consulting his English monolingual dictionary application he could not avoid the use of bilingual dictionary application to get word choices that could be use. E.g. he once found that most of his students translated "melakukan" by using "do" then it was too common, then he consulted his bilingual dictionary application to find other choices of words. Then he found " do, perform, commit, make, take, carry out, exercise, realize, conduct, execute, realize, hold, undertake, carry on, handle, take on, administer, bring about, carry through, pull off, tackle, ply, bring off, effectuate, and play out". Then he used his English monolingual dictionary application to consult those. Finally, he got "execute, commit, administer" that were probably suitable for writing about corruption. Execute means, "to do piece of work, perform a duty, put a plan into action, etc. and to kill somebody especially as a legal punishment." Commit means, "to do something wrong or illegal", While Conduct means, "to organize and/ to do 
a particular activity formally." Those words are often used to suggested for his academic writing students.

There are some advantages obtained from using EMDA. Mr. Asyrof stated that he had felt the great benefits a lot; he could consult the word information required more quickly. To use a conventional dictionary must have taken longer time to find the words. Because of English Monolingual Dictionary Application 's existence, his teaching and his evaluation was easier, he also mentioned "if there is something which is able to make our work more effective and efficient, why do we not optimize it?" Likewise, he highly recommended his academic writing students, moreover academic writing teachers to utilize the benefits of the advanced technology after he himself obtained the easiness of consulting the unfamiliar words both in teaching and evaluating his students writing.

Mr farid felt the assistance so much as well, because of English Monolingual Dictionary Application 's existence his job was getting easier and easier and he also could give more accurate suggestions for his students' especially the diction and grammatical correctness; moreover, the English Monolingual Dictionary Application could be used as a source or reference of knowledge. In the end, he recommended the writing teachers to use English Monolingual Dictionary Application as well because the assistance that he had already got . 


\section{Conclusion}

Based on the data analysis, several points to conclude are: The English Monolingual Dictionary Application used by the key informants in this study were Oxford Advance Learner's Dictionary (OALD) $9^{\text {th }}$ edition and Longman Dictionary of Contemporary English (LDOCE) 6th edition. Those met the requirements of good dictionary such as containing plenty of words, and there is a lot of information about words like the parts of speech, phonetic symbols and their implementation in sentences.

The English monolingual dictionary applications have been used according to their appropriate functions such as checking spelling, confirming meaning or word definition, consulting word usage through examples of sentences. The English Monolingual Dictionary Application has also been the great technological assistance for teachers or informants. It has been proven to be highly effective tool in terms of time and portability or simply mean that application can be operated every time and wherever the teachers are.

The teachers cannot only consult English Monolingual Dictionary application but they also consult bilingual dictionary application in order that they can optimize their feedback towards their students writing products. They use bilingual dictionary application to find possible English words for an Indonesian word (e.g. Indonesian word "melakukan" may be translated as do, perform, commit, make, take, carry out, exercise, realize, conduct, execute, realize, hold, undertake, carry on, handle, take on, 
administer, bring about, carry through, pull off, tackle, ply, bring off, effectuate, and play out. Then to check their meaning to suit the context they use English monolingual dictionary application.

After analyzing the findings, the researcher wants to give some suggestions to the next researcher, the English teacher, and reader. For the next researcher, this study is still far from perfection, it is suggested that the next researcher can develop this research about student's perception towards teachers using English Monolingual Dictionary Application in the class or when evaluating writing. Likewise, the next researcher can observe the use of English Monolingual Dictionary Application at a program called English Comprehension especially for Pronunciation Class at Kresna English Institute. For the English writing teachers, they are expected to be able to use or consult English Monolingual Dictionary Application because this research showed that English Monolingual Dictionary Application provided so much help to support teaching in the class especially when evaluating student's writing product. Furthermore, OALD and LDOCE have been in the version. It is better for teachers to have more mobile monolingual learner's Dictionaries such as Meriam Webster and Cambridge because the number of words is different, that it is possible that English Monolingual Dictionary Application users cannot find a word on OALD but they can find it on Meriam Webster. E.g. "befoul" cannot be found on OALD but it can be found on Meriam Webster. The researcher hopes that the teachers can be wiser to evaluate students' writing. They do not easily blame students' 
dictions after consulting the problems through English Monolingual Dictionary Application. For the readers, they can get information about what English Monolingual Dictionary Application and the benefit of using or consult it.

\section{About the Writer}

Muarfian Suryanudin majored in English Education. After graduated from Kadiri Islamic University, he has been focusing his works as a social media content creator in which he makes contents related to English Language Teaching. He has also been teaching at Kresna Language Institute in Pare for the past few years. His research interests are in grammar and vocabulary teaching and learning, and speaking skills.

\section{References}

Alexander, L.G., 1975. Practice and Progress, (London: Longman Group Ltd, p. VIII. Language Learning: From Content Delivery to Supported Collaboration and Interaction. Re-CALL, 20, 271-289. https://doi.org/10.1017/S0958344008000335

Brown, D, H. 2000. Principle of Language Learning and Teaching. The fourth edition: Addison Wesly Longman, Inc.

Brown, D, H. 2001. Teaching by Principles. The second edition: Addison Wesly Longman, Inc.

Celce-Murcia, M., and Larsen-Freeman, D. 1999. The Grammar Book: An ESL/EFL Teacher's Course (2nd ed.). Boston, MA: Heinle and Heinle. 
Chinnery, G. 2006. Emerging Technologies - Going to the MALL: Mobile Assisted Language Learning. Language Learning and Technology, 10(1), 9-16. istepi

Koç, Sabri and Brian Bamber.1997. English Language Teaching. Ankara: YÖK.

Kukulska-Hulme, A., and Shield, L. 2008. An Overview of Mobile Assisted

Nunan, D. 1991. Language Teaching Methodology. New York: Prentice Hall.

Nunan, D. 1999. Second Language Teaching and Learning. Boston, Massachusetts,

Richard, Jack C and Willy A Renandya. (2002). Methodology in Language Teaching: An Anthology of Current Practice. Cambridge University.

Steel, C. 2012. Fitting learning into life: Language students' perspectives on benefits of using mobile apps. Proceedings of ascilite2012, Future Challenges Sustainable Future. Wellington, New Zealand. Available at:

http://www.ascilite.org.au/conferences/wellington12/2012/images/cust om/steel\%2c_caroline_-_fitting_learning.pdf.

Thorburry, S. (2002). How to teach vocabulary. England: Pearson Education Limited.Ur, P., (1998). A course in language teaching. Cambridge: University Press.

Thornton, P., and Houser, C. (2005). Using mobile phones in English education in Japan. Journal of Computer Assisted Learning, 21, 217228.http://dx.doi.org/10.1111/j.1365-2729.2005.00129.x

Ur, P. (1996) A course in Language Teaching: Practice and Theory. Cambridge University Press, Cambridge. 